\title{
PENGEMBANGAN MODEL ASSESSMENT FOR LEARNING PADA PEMBELAJARAN MATEMATIKA DI SMP
}

\author{
Mansyur \\ Fakultas Teknik Universitas Negeri Makassar \\ Kampus Gunungsari Baru Jl. A.P. Pettarani Makassar 90222 \\ aura_fz@yahoo.co.id
}

\begin{abstract}
Abstrak
Tujuan penelitian ini adalah untuk menemukan cara mengembangkan model assessment for learning pada pembelajaran matematika. Penelitian ini merupakan penelitian pengembangan model Hopkins \& Clark. Subjek uji coba adalah 20 orang guru matematika dan 199 orang siswa kelas VII SMPN 13 dan SMPN 27 Makasar. Analisis data dilakukan dua tahap dan secara kualitatif dan kuantitatif. Ujicoba model AfL menggunakan repeated measures analysis. Hasil penelitian menunjukkan bahwa model assessment for learning yang dikembangkan memiliki lima karakteristik utama. pembelajaran lebih memberikan rasa keadilan bagi semua siswa, dan cocok diterapkan untuk semua mata pelajaran. Beberapa temuan dalam penelitian ini yaitu: (1) informasi yang diperoleh melalui penggunaan Model-AfL akurat dan sesuai dengan kebutuhan nyata siswa dan (2) penerapan Model-AfL dalam pembelajaran matematika meningkatkan motivasi, kepercayaan diri, kesadaran diri siswa, perilaku siswa selama pembelajaran, dan kemampuan siswa terhadap matematika; dan (3) kemajuan belajar siswa ditampilkan melalui profil individu dan profil kelas.
\end{abstract}

Kata kunci: asesmen, asesmen formatif, assessment for learning, pendidikan matematika, pembelajaran 
Jurnal Penelitian dan Evaluasi Pendidikan

\title{
DEVELOPMENT OF AN ASSESSMENT-FOR-LEARNING MODEL IN MATHEMATICS LEARNING IN JUNIOR HIGH SCHOOLS
}

\author{
Mansyur \\ Fakultas Teknik Universitas Negeri Makassar \\ Kampus Gunungsari Baru Jl. A.P. Pettarani Makassar 90222 \\ aura_fz@yahoo.co.id
}

\begin{abstract}
This study aimed to develop an assessment-for-learning (AfL) model in mathematics learning. This was a research and development study using the Hopkins \& Clark model. The tryout subjects consisted of 20 mathematics teachers and 199 Year VII students of SMPN 13 and SMPN 27 Makasar. The data were analyzed in two stages by means of quantitative and qualitative techniques. The tryout of the AfL model used a repeated measures analysis. The results show that the developed AfL model has five main characteristics. The model provides all students with fairness and is appropriate for all subjects. Some research findings show that: (1) information obtained through the application of the AfL model is accurate and relevant to the students' real needs; (2) the application of the AfL model in mathematics learning improves students' motivation, selfconfidence, self-awareness, behaviors during the learning process, and competence in mathematics; and (3) students' learning progress is presented through the individual and class profiles.
\end{abstract}

Keywords: assessment, formative assessment, assessment for learning, mathematics education, and learning 


\section{Pendahuluan}

Penilaian dalam pembelajaran matematika merupakan bagian tidak terpisahkan dari proses pendidikan matematika. Upaya peningkatan kualitas pendidikan matematika dapat ditempuh melalui peningkatan kualitas pembelajaran dan kualitas sistem penilaian. Kualitas pembelajaran ini dapat dilihat dari hasil penilaiannya. Sebaliknya, sistem penilaian yang baik, akan mendorong guru untuk menentukan strategi yang tepat dan memotivasi siswa untuk belajar lebih baik. Salah satu bentuk penilaian yang diharapkan untuk hal tersebut adalah penilaian formatif. Namun demikian, kenyataan di lapangan, di sekolah-sekolah, baik dalam konteks internasional maupun domestik, penilaian formatif masih belum berfungsi.

Dalam konteks internasional, bukti terlihat dari hasil penelitian Fair Test Examiner (1999) menunjukkan bahwa penilaian formatif relatif jarang dilaksanakan di kelas, dan sebagian besar guru tidak mengetahui bagaimana menggunakan penilaian tersebut. Hasil yang sama dikemukakan oleh Black dan William (1998) bahwa sebagian besar pengujian di kelas mendorong belajar superfisial dan hafalan. Para guru tidak dapat menolong guru yang lainnya menjadi penilai yang baik, dan mereka sering menekankan kuantitas dari pada kualitas pekerjaan. Para guru, biasanya mereplikasi tes terstandarisasi dalam praktik penilaian mereka sendiri, sehingga kurang memberi informasi tentang siswa mereka.

Kemudian, dalam konteks Indonesia, pelaksanaan penilaian formatif pada pembelajaran matematika tidak jauh berbeda dengan internasional. Setidaknya hal tersebut dikuatkan dari hasil penelitian Zulkardi (2002) yang menyimpulkan bahwa dalam melakukan penilaian pembelajaran matematika, guru masih menggunakan format penilaian yang lemah. Alat penilaian yang belum dirancang dengan baik dan ditekankan pada hasil dari pada proses, masih mendominasi penilaian. Selanjutnya, Kusnanto (2006) melaporkan hasil survei tehadap siswa sekolah menengah di Semarang bahwa, siswa cenderung tidak memiliki sikap yang benar saat belajar matematika. Salah satu penyebabnya karena sistem penilaian buruk. 
Hasil penelitian pendahuluan dan wawancara yang peneliti lakukan terhadap guru matematika SMP dan Madrasah Tsanawiah di Sulawesi Selatan mendukung kesimpulan yang dikemukakan di atas bahwa: (1) penilaian formatif belum berfungsi untuk mendiagnosis kesulitan belajar matematika siswa dan (2) guru belum memiliki kebiasaan untuk melakukan analisis diagnosis kesulitan belajar siswa. Hasil temuan awal tersebut, menguatkan kesimpulan hasil penelitian Kumaidi (2005) terhadap guruguru di Sumatera Barat bahwa guru kurang memiliki pemahaman dan keterampilan pengujian, mulai dari pengembangan dokumen pengembangan tes, penulisan butir soal, telaah silang dan perbaikan soal, editing dan penyuntingan akhir, juga keterampilan melakukan analisis diagnostik. Selanjutnya, Kumaidi mengatakan bahwa penilaian untuk tujuan diagnostik (pemanfaatan diagnostik kesulitan belajar siswa) pada dasarnya jarang atau bahkan tidak dilakukan guru karena (1) kebanyakan guru tidak dapat melaksanakan analisis diagnostik kesulitan belajar siswa dan (2) tidak menjadi kebiasaan guru, guru lebih sering melaksanakan tujuan grading.

Akibat dari belum berfungsinya penilaian formatif pada level kelas, maka kualitas pembelajaran matematika masih belum tercapai. Setidaknya hal tersbut terlihat dari hasil studi TIMMS tahun 2006 yang menempatkan siswa-siswa Indonesia berada pada urutan 34 dari 38 negara yang disurvai. Untuk mengatasi kelemahan praktik penilaian formatif yang telah dikemukakan di atas dan untuk peningkatan kualitas kemampuan matematika, peneliti menawarkan suatu model penilaian yang terintegrasi dengan pembelajaran, yaitu model assessment for learning (Model-AfL) (Mansyur, 2009). Model ini merupakan hasil dari penelitian pengembangan yang dilakukan dengan menggunakan model pengembangan hasil penyesuaian dari the R, D, \& D model yang dikembangkan oleh Hopkins \& Clark (Havelock, 1976) dengan tujuan untuk menguji apakah model-AfL dapat meningkatkan kemampuan matematika siswa.

Tujuan penelitian ini adalah untuk (1) menemukan cara mengembangkan model assessment for learning, (2) mengetahui informasi apa saja yang dapat dimunculkan jika menggunakan model assessment for learning, (3) mengetahui bentuk pemanfaatan informasi hasil penilaian dengan menggunakan model assessment for learning, (4) mengetahui apakah model

74 - Jurnal Penelitian dan Evaluasi Pendidikan Tahun 15, Nomor 1, 2011 
assessment for learning dapat berfungsi untuk meningkatkan pemahaman, perilaku, dan kemampuan siswa, dan (5) mengetahui cara pelaporan hasil penilaian dengan menggunakan model assessment for learning pada pembelajaran matematika. Pada tulisan ini, peneliti hanya menyajikan tujuan penelitian yang ketiga yaitu khusus pada peningkatan kemampuan matematika melalui penerapan model assessment for learning.

Konsep assessment for learning pada dasarnya bukanlah hal baru dalam penilaian pendidikan, tetapi wujud penerapannya dalam konteks perbaikan dan peningkatan kualitas pembelajaran, assessment for learning lebih baik, terencana, terarah, dan terfokus. Setidaknya hal tersebut tercermin dari pengertian assessment for learning yang dikemukakan dalam Assessment Reform Group (2002), yang mengatakan bahwa:

Assessment for learning is the process of seeking and interpreting evidence for use by learners and their teachers to decide where the learners are in their learning, where they need to go and how best to get there.

Penekanan dari pengertian assessment for learning terletak pada proses perolehan informasi dan pemanfaatan informasi. Informasi atau keterangan diperoleh melalui kerjasama antara guru dengan siswa dan informasi tersebut dimanfaatkan oleh mereka (guru dan siswa) untuk perbaikan dan peningkatan kualitas pembelajaran berikutnya. Bagi guru, informasi digunakan untuk perbaikan dan penyempurnaan strategi pengajaran sesuai dengan kebutuhan nyata para siswanya. Sementara bagi siswa, dapat digunakan sebagai dasar dalam mengubah strategi belajar yang lebih baik. Pengertian yang hampir sama dikemukakan juga dalam Pearson Education (2006), yaitu:

Assessment for learning is a collaborative process between teacher and pupil, and with pupils engaging with each other in structuring their own learning. It is built on a foundation of shared learning objectives and shared criteria for success. Pupils are given the criteria for success and the support they need to achieve that success. Feedback, either during or on completion of the task, is essential if pupils are to know what else is must be done to ensure further learning. Pupils are provided with opportunities to participate in self- or peer-assessment as this develops an understanding of personal responsibility in learning. 
Tampak pada pengertian terakhir, bahwa penekanannya juga terletak pada kolaborasi antara guru dengan siswa maupun antara sesama siswa. Kolaborasi mereka dalam kaitan dengan kegiatan pembelajaran dalam upaya menjadikan semua siswa sukses. Untuk mencapai kesuksesan tersebut, tugas guru seperti sharing tujuan pembelajaran dan kriteria sukses di awal pelajaran juga menjadi penekanan definisi tersebut. Pemberian masalah secara terstruktur untuk dikerjakan oleh siswa, kemudian guru memberikan umpan balik atas pekerjaan mereka, sehingga diperoleh informasi tentang kekuatan dan kelemahan siswa.

Model-AfL dalam penelitian ini mengadopsi kedua pengertian assessment for learning yang dikemukakan dalam Assessment Reform Group dan Pearson Education, yang memberi penekanan pada kolaborasi antara guru dan siswa serta pemanfaatan informasi hasil penilaian untuk memodifikasi strategi dan teknik mengajar dan belajar.

Operasionalisasi pengertian assessment for learning dalam kerangka tujuan, dinyatakan dalam CEA (2003) yang mengatakan bahwa tujuan assessment for learning untuk:

a. memberi wawasan pembelajaran kepada guru dan siswa dalam upaya meningkatkan kesuksesan untuk semua,

b. membantu proses penetapan tujuan,

c. memungkinkan refleksi secara kontinyu terhadap apa yang siswa ketahui sekarang dan apa yang mereka butuhkan untuk diketahui berikutnya,

d. mengukur apa yang dinilai,

e. menetapkan intervensi secara cepat dan tepat sesuai dengan tujuan pembelajaran, dan

f. meningkatkan standar yang diperoleh siswa.

Sehubungan dengan tujuan tersebut, kesuksesan dalam pembelajaran diperuntukkan bagi guru maupun siswa. Guru dituntut memiliki wawasan dan kemampuan profesional tentang pembelajaran, misalnya penguasaaan materi, perencanaan, penetapan tujuan pembelajaran, dan membuat keputusan yang tepat, sehingga siswa termotivasi untuk memperbaiki dan meningkatkan belajarnya.

76 - Jurnal Penelitian dan Evaluasi Pendidikan Tahun 15, Nomor 1, 2011 
Untuk merealisasikan tujuan yang telah dikemukakan di atas, Assessment Reform Group (2002) memberikan sepuluh prinsip utama, yaitu assessment for learning:

a. should be part of effective planning of teaching and learning

b. should focus on how students learn

c. should be recognized as central to classroom practice

d. should be recognized as a key professional skill for teachers

e. should be sensitive and constructive because any assessment has an emotional impact

f. should take account of the importance of learner motivation

g. should promote commitment to learning goals and a shared understanding of the criteria by which they are assessed

h. learners receive constructive guidance about how to improve

$i$. develops learners capacity for self-assessment so that they can become reflective and self-managing

$j$. should recognize the full range of achievements of all learners

Aplikasi dari pengertian, tujuan, dan prinsip assessment for learning dalam pelaksanaan penilaian di kelas, maka disusun sintaks model-AfL. Sintak ini merupakan panduan dan petunjuk praktis bagi praktisi pendidikan, guru, dosen dalam penerapannya di dalam kelas. Sebagai panduan dalam pelaksanaan uji model secara empirik, maka hipotesis penelitian ini dirumuskan sebagai "Penerapan model-AfL dapat meningkatkan kemampuan matematika siswa".

\section{Metode Penelitian}

Penelitian ini merupakan penelitian pengembangan dengan mengadopsi model yang dikembangkan oleh Hopkins \& Clark yaitu the $R$, $D \& D$ model' (Havelock, 1976). Pada tahap research, ada 4 tahap kegiatan yang dilakukan, yaitu penelitian pendahuluan, studi hasil-hasil penelitian, analisis kurikulum, dan penyusunan prototype model. Pada tahap development, ada 5 tahap kegiatan yang dilakukan, yaitu: validasi pakar, uji keterbacaan, latih guru, ujicoba terbatas, dan ujicoba diperluas. Pada tahap diffussion, ada 
3 kegiatan yang dilakukan, yaitu diseminasi, pelatihan, dan demonstrasi. Disain penelitian pengembangan ini disajikan pada Gambar 1.

Prosedur pengembangan model assessment for learning mengacu pada disain yang telah dikemukakan di atas. Secara operasional, prosedur pengembangan yang dilaksanakan yaitu:

a. Menyusun perangkat model, yaitu panduan praktis penggunaan model, instrumen penilaian efektivitas model, instrumen penilaian diri siswa, instrumen tugas dua tahap, kriteria dan rubrik penskoran, dan rencana pelaksanaan pembelajaran.

b. Validasi pakar.

c. Revisi.

d. Keterbacaan perangkat pada guru-guru matematika SMP.

e. Validasi pakar, keterbacaan, dan revisi prosesnya berulang.

f. Latih guru.

g. Ujicoba terbatas.

h. Revisi model.

i. Ujicoba diperluas.

j. Ditemukan model assessment for learning yang fit antara kerangka teoritis dengan data empirik.

Pembuktian efektivitas model secara empirik dalam kerangka penelitian pengembangan menggunakan pendekatan kuasi eksperiman dengan disain single-group interrupted time-series design (Creswell, 1994: 133). Rancangan disain tersebut disajikan pada Tabel 1. 


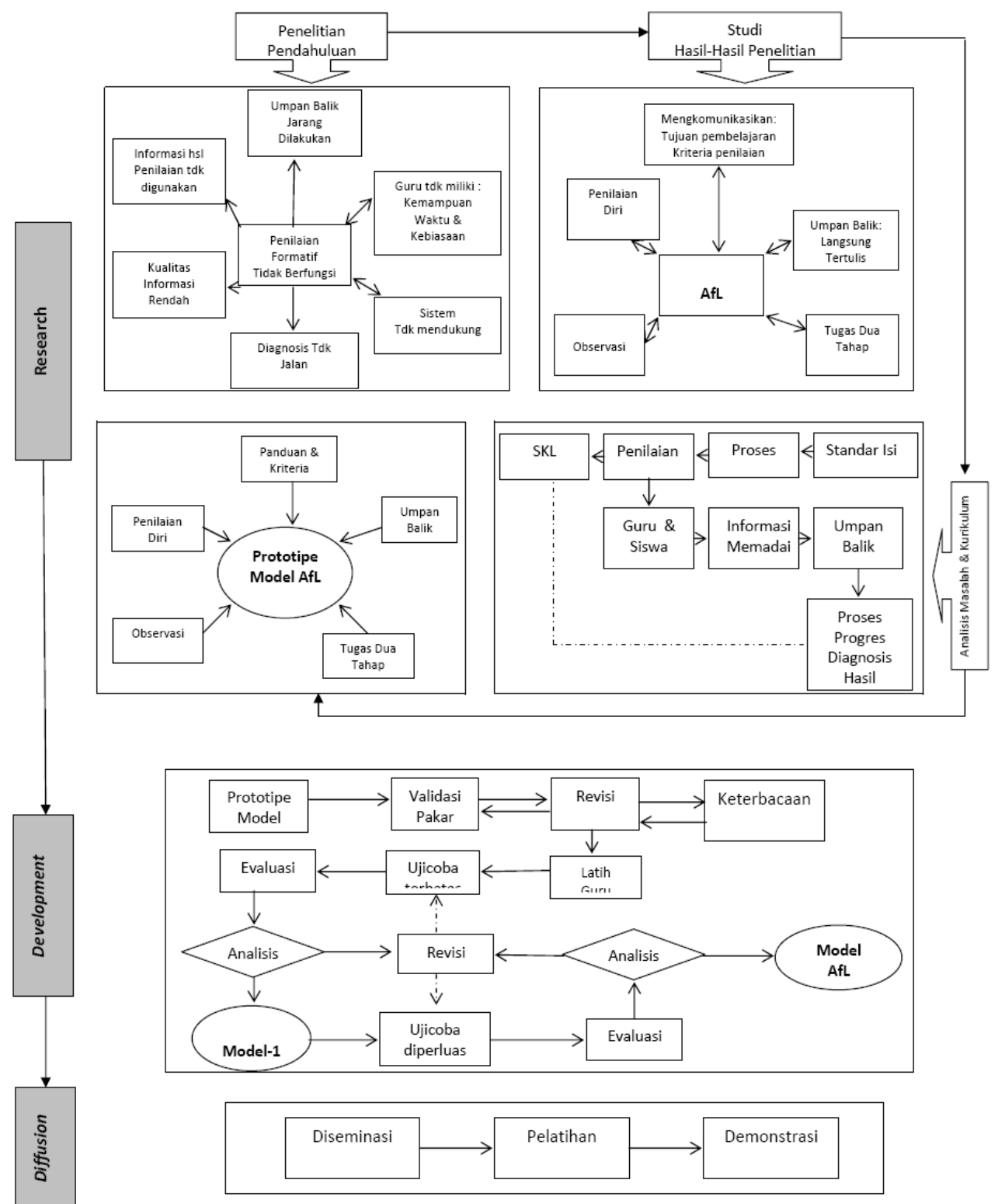

Gambar 1. Disain Pengembangan Model-AfL 
Tabel 1. Single-Group Interrupted Time-Series Design untuk Uji Coba Model

\begin{tabular}{cccccc}
\hline Pertemuan ke- & 1 & 2 & 3 & 4 & 5 \\
\hline Kelas A & $\mathrm{X}^{-\mathrm{O}_{1}}$ & $\mathrm{X} / \mathrm{O}_{2}$ & $\mathrm{X} / \mathrm{O}_{3}$ & $\mathrm{X} / \mathrm{O}_{4}$ & $\mathrm{X} / \mathrm{O}_{5}$ \\
\hline
\end{tabular}

Keterangan:

$\mathrm{X}=$ perlakuan

Oi $=$ pengukuran kemampuan matematika siswa, $i=1,2, \ldots 5$.

Pelaksanaan ujicoba terbatas dan ujicoba diperluas masing-masing 2 bulan (setara dengan 16 kali pertemuan), yaitu dimulai pada bulan November 2007 sampai dengan bulan Februari 2008, dengan banyaknya pengukuran yang dilakukan 5 kali. Perlakuan dan observasi dilaksanakan bersamaan dalam suatu pertemuan. Sebelum pelaksanaan ujicoba peneliti terlebih dahulu mengontrol validitas internal dan validitas eksternal.

Responden penelitian terdiri atas guru dan siswa, keterlibatan kedua responden ini tergantung pada kebutuhan pada fase pengembangan. Untuk responden ujicoba terbatas, dipilih 1 kelas sebagai kelas perlakuan. Responden dari unsur guru dipilih 4 orang yang mengajar mata pelajaran matematika pada sekolah yang dijadikan sebagai tempat ujicoba terbatas (SMP negeri 27 Makassar). Guru tersebut, 1 orang untuk mengajar, dan 2 orang untuk dijadikan sebagai pengamat. Subjek coba untuk ujicoba diperluas, dipilih 2 sekolah, masing-masing terdiri atas 2 kelas. Setiap kelas diajar oleh masing-masing seorang guru dan diamati oleh seorang pengamat (dari unsur guru). Semua guru yang dijadikan sebagai responden penelitian berjumlah 20 orang, sebelum terjun ke kelas dilatih oleh peneliti tentang penggunaan Model-AfL. Subjek penelitian yang terlibat dalam tahap pengembangan model disajikan pada Tabel 2.

Tabel 2. Sebaran Subjek Penelitian

\begin{tabular}{|c|c|c|c|c|}
\hline \multirow{2}{*}{ Jenis Subjek } & \multicolumn{3}{|c|}{ Jumlah Subjek Ujicoba } & \multirow{2}{*}{ Jumlah } \\
\hline & Keterbacaan & Terbatas & Diperluas & \\
\hline Siswa & 10 orang & 39 orang & 150 orang & 199 orang \\
\hline Guru & 7 orang & 4 orang & 9 orang & 20 orang \\
\hline
\end{tabular}


Metode pengumpulan data dan instrumen yang akan digunakan dalam pengembangan ini terdiri atas beragam teknik yang penggunaannya disesuaikan dengan kebutuhan dan jenis data yang dikumpulkan sesuai dengan tahap-tahap kegiatan pengembangan. Pada dasarnya ada dua kelompok instrumen, yaitu instrumen pengumpul data dan instrumen perlakuan. Instrumen perlakuan terdiri atas penilaian diri siswa, dan tugas dua tahap. Instrumen perlakuan ini sekaligus sebagai instrumen pengumpul data. Jadi instrumen pengumpul data terdiri atas lembar pengamatan perilaku, tugas dua tahap (untuk mengukur kemampuan dan miskonsepsi siswa terhadap materi pelajaran yang diberikan), dan lembar penilaian diri siswa.

Validitas dan reliabilitas hasil pengukuran instrumen-instrumen yang digunakan akan dilakukan tindakan validasi (Nitko \& Brookhard, 2007: 3844). Instrumen tugas dua tahap akan dilihat beberapa dimensi persyaratan alat ukur tes antara lain tingkat kesulitan, reliabilitas, validitas, dan daya pembeda soal (Cohen \& Swerdlik, 2005: 212). Kemudian, untuk mengukur tingkat kesepakatan antar penilai (inter-rater reliability) terhadap instrumen lembar penilaian diri, lembar pengamatan perilaku, angket efektifitas model, keterlaksanaan model dalam kelas, dan lembar penilaian model hasil validasi digunakan koefisien Cohen's Kappa (Cohen, 2001: 657) dan percentages of agreements (Grinnell, 1988: 160). Untuk menghitung koefisien Cohen's Kappa ( $\kappa)$ digunakan formula yang dikemukakan oleh Cohen (2001: 657) sebagai berikut:

$$
\kappa=\frac{\sum f_{0}-\sum f_{e}}{N-\sum f_{e}}
$$

dimana:

$\kappa=$ tingkat kesepakatan penilai (koefisien reliabilitas antar penilai)

$\mathrm{f}_{0}=$ frekuensi hasil pengamatan

$\mathrm{fe}=$ frekuensi yang diharapkan

$\mathrm{N}=$ banyaknya butir soal yang dinilai (diklasifikasi) 
Kemudian untuk menghitung tingkat percentages of agreements antara kedua penilai yang datanya hanya ya atau tidak digunakan rumus yang dikemukakan oleh Grinnell (1988: 160) sebagai berikut,

$$
\text { Percentages of agreements }=\frac{\text { Agreements }}{\text { (Disagreements }+ \text { Agreements })} \times 100
$$

Batas bawah koefisien reliabilitas yang digunakan untuk suatu tes yang baik yaitu sebesar 0,70 (Linn, 1989: 106 ).

Analisis data hasil penelitian pendahuluan dilakukan dengan menggunakan pendekatan deskriptif disertai dengan narasi yang sesuai dengan kepentingan penelitian. Analisis data pada saat pengembangan model dilakukan dengan pendekatan kualitatif dan kuantitatif. Analisis kualitatif dilakukan untuk menganalisis data hasil validasi model oleh para ahli yang memberikan masukan dalam rangka perbaikan. Analisis kualitatif juga digunakan untuk menganalisis data hasil penilaian diri siswa terhadap pertanyaan-pertanyaan terbuka yang diberikan. Analisis untuk mengetahui perkembangan kemampuan, penilaian diri, dan perilaku siswa selama/ setelah ujicoba model AfL digunakan repeated measures analysis (Field, 2000: 326) dengan desain analisis data disajikan pada Tabel 3.

Tabel 3. Repeated Measures Design untuk Analisis Data

\begin{tabular}{|c|c|c|c|c|c|c|}
\hline & \multicolumn{5}{|c|}{ Pertemuan } \\
\hline & & 1 & 2 & 3 & 4 & 5 \\
\hline \multirow{7}{*}{$\frac{\frac{y}{0}}{\frac{0}{\vec{n}}}$} & 1 & Y11 & $\mathrm{Y} 12$ & Y13 & Y14 & Y15 \\
\hline & 2 & Y21 & Y22 & $\mathrm{Y} 23$ & Y24 & Y25 \\
\hline & 3 & Y31 & Y32 & Y33 & Y34 & Y35 \\
\hline & . & & . & . & & . \\
\hline & . & . & . & . & . & . \\
\hline & $\cdot$ & . & . & . & . & . \\
\hline & $\mathrm{N}$ & Yn1 & Yn2 & Yn3 & Yn4 & Yn5 \\
\hline
\end{tabular}

82 - Jurnal Penelitian dan Evaluasi Pendidikan Tahun 15, Nomor 1, 2011 


\section{Hasil Penelitian dan Pembahasan}

Hasil validasi model oleh para pakar menunjukkan bahwa perangkat model seperti panduan dan instrumen model telah memenuhi syarat validitas dan reliabilitas. Semua hasil validasi pakar memberikan penilaian bahwa model layak digunakan tanpa revisi. Hasil uji efektivitas model secara empiris merupakan jawaban dari hipotesis penelitian. Uji efektivitas model-AfL secara empiris dilakukan dengan menggunakan analisis repeated measures. Dalam analisis, variabel yang diperhatikan adalah kemampuan siswa pada pengukuran yang berulang (repeated measures), dalam hal ini pengukuran dilakukan sebanyak 5 kali pada 2 sekolah masing-masing sekolah untuk 2 kelas. Untuk melakukan analisis dengan repeated measures, terlebih dahulu dilakukan uji asumsi, yaitu asumsi sphericity (Field, 2000: 333, Stevens, 1996: 459). Untuk keperluan pengujian asumsi tersebut, digunakan Mauchly's Test of Sphericity. Asumsi yang diuji adalah:

Ho : Matriks kovarians kesalahan hasil transformasi ortonormal dari variabel yang diperhatikan $=$ matriks identitas

lawan

H1 : Matriks kovarians kesalahan hasil transformasi ortonormal dari variabel yang diperhatikan $\neq$ matriks identitas

Kriteria pengujian: terima hipotesis $\mathrm{H}_{0}$ jika nilai signifikansi hasil perhitungan $p \geq \alpha$, sebaliknya $\mathrm{H}_{0}$ ditolak (Miller \& Miller, 2004: 402). Hasil perhitungan uji asumsi tersebut dirangkum pada Tabel 4. Informasi yang disajikan dalam Tabel 4 tersebut, yaitu nilai statistik untuk Mauchly's test sebesar 0,235 dan signifikansi hasil perhitungan $p$ sebesar 0,000001. Jika nilai signifikansi hasil perhitungan dibandingkan dengan signifikansi $\alpha=$ 0,05 , maka $\alpha>p$. Dengan demikian asumsi sphericity tidak terpenuhi. Field (2000: 333) mengatakan bahwa jika asumsi sphericity tidak terpenuhi, maka dapat dilakukan koreksi dengan melihat salah satu dari Epsilon (Greenhous e-Geisser, Huynh-Feldt, atau Lower-bound). Pada analisis ini, peneliti memilih Epsilon Greenhous e-Geisser yang nilai signifikansi hasil perhitungan $\varepsilon$ 
sebesar 0,863. Jika nilai $\varepsilon$ ini dikaitkan dengan kriteria, yaitu $\frac{1}{k-1} \leq \varepsilon \leq 1$ ( $\mathrm{k}$ banyak pengukuran, dalam hal ini $\mathrm{k}=5$ ), maka $\varepsilon$ yang diperoleh terletak dalam interval tersebut. Dengan demikian, dapat disimpulkan bahwa asumsi sphericity terpenuhi, sehingga uji repeated measures dapat dilanjutkan.

Tabel 4. Rangkuman Hasil Perhitungan Mauchly's Test of Sphericity

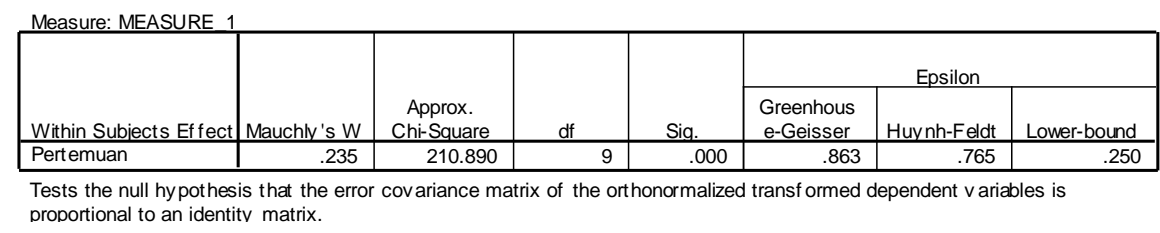

Persyaratan analisis repeated measures terpenuhi sehingga dapat dilakukan analisis selanjutnya. Hasil perhitungan analisis repeated measures uji multivariat dirangkum pada Tabel 5. Perlakuan (penerapan model-AfL) untuk setiap pertemuan maupun interaksi antara pertemuan dengan kelas menunjukkan pengaruh yang signifikan. Setidaknya hal tersebut diperlihatkan oleh nilai signifikansi hasil perhitungan ( $p$ ) masing-masing pertemuan dan interaksi pertemuan dengan kelas lebih kecil dari nilai signifikansi $\alpha=0,05$ yang dipilih. Dengan demikian, dapat dsimpulkan bahwa penerapan model-AfL dalam pembelajaran matematika memberikan pengaruh yang signifikan terhadap peningkatan kemampuan matematika siswa.

Tabel 5. Rangkuman Hasil Perhitungan Uji Multivariate pada Analisis Repeated Measures

\begin{tabular}{|ll|r|r|r|r|r|}
\hline & & & & & \\
& & Value & \multicolumn{1}{|c|}{ F } & Hypothesis df & \multicolumn{1}{c|}{ Error df } & Sig. \\
\hline Pertemuan & Pillai's Trace & .401 & $24.086^{\mathrm{a}}$ & 4.000 & 144.000 & .000 \\
& Wilks' Lambda & .599 & $24.086^{\mathrm{a}}$ & 4.000 & 144.000 & .000 \\
& Hotelling's Trace & .669 & $24.086^{\mathrm{a}}$ & 4.000 & 144.000 & .000 \\
& Roy's Largest Root & .669 & $24.086^{\mathrm{a}}$ & 4.000 & 144.000 & .000 \\
\hline Pertemuan * Kelas & Pillai's Trace & .327 & 4.471 & 12.000 & 438.000 & .000 \\
& Wilks' Lambda & .700 & 4.579 & 12.000 & 381.280 & .000 \\
& Hotelling's Trace & .389 & 4.628 & 12.000 & 428.000 & .000 \\
& Roy's Largest Root & .255 & $9.323^{\mathrm{b}}$ & 4.000 & 146.000 & .000 \\
\hline
\end{tabular}

a. Exact statistic

b. The statistic is an upper bound on $\mathrm{F}$ that $\mathrm{y}$ ields a lower bound on the significance level. 
Hasil uji multivariate tersebut dikuatkan dari hasil tests of within-subjects effects seperti yang disajikan pada Tabel 6 .

Tabel 6. Rangkuman Hasil Perhitungan Tests Of Within-Subjects Effects pada Analisis Repeated Measures

\begin{tabular}{|c|c|c|c|c|c|c|}
\hline Source & & $\begin{array}{l}\text { Type III Sum } \\
\text { of Squares }\end{array}$ & $\mathrm{df}$ & Mean Square & $\mathrm{F}$ & Sig. \\
\hline \multirow[t]{4}{*}{ Pertemuan } & Sphericity Assumed & 478.079 & 4 & 119.520 & 74.611 & .000 \\
\hline & Greenhouse-Geisser & 478.079 & 2.503 & 191.025 & 74.611 & .000 \\
\hline & Huynh-Feldt & 478.079 & 2.601 & 183.772 & 74.611 & .000 \\
\hline & Lower-bound & 478.079 & 1.000 & 478.079 & 74.611 & .000 \\
\hline \multirow[t]{4}{*}{ Pertemuan * Kelas } & Sphericity Assumed & 80.261 & 12 & 6.688 & 4.175 & .000 \\
\hline & Greenhouse-Geisser & 80.261 & 7.508 & 10.690 & 4.175 & .000 \\
\hline & Huynh-Feldt & 80.261 & 7.804 & 10.284 & 4.175 & .000 \\
\hline & Lower-bound & 80.261 & 3.000 & 26.754 & 4.175 & .007 \\
\hline \multirow[t]{4}{*}{ Error(Pertemuan) } & Sphericity Assumed & 941.925 & 588 & 1.602 & & \\
\hline & Greenhouse-Geisser & 941.925 & 367.896 & 2.560 & & \\
\hline & Huynh-Feldt & 941.925 & 382.418 & 2.463 & & \\
\hline & Lower-bound & 941.925 & 147.000 & 6.408 & & \\
\hline
\end{tabular}

a. Computed using alpha $=.05$

Mencermati Tabel 6, tampak bahwa perlakuan (penerapan modelAfL) untuk setiap pertemuan maupun interaksi antara pertemuan dengan kelas menunjukkan pengaruh yang signifikan. Hal tersebut diperlihatkan oleh nilai signifikansi hasil perhitungan $(p)$ masing-masing pada baris pertemuan $(p=0,0001)$ dan pertemuan* kelas $(p=0,0001)$ lebih kecil dari nilai signifikansi $\alpha=0,05$ yang dipilih. Dengan demikian, dapat disimpulkan bahwa penerapan model-AfL dalam pembelajaran matematika memberikan pengaruh signifikan terhadap peningkatan kemampuan matematika siswa.

Selanjutnya, dilakukan uji untuk mengetahui apakah pengaruh tersebut bersifat linier atau tidak. Untuk keperluan tersebut digunakan tests of within-subjects contrast, yang hasilnya dirangkum pada Tabel 7. Tampak pada Tabel 7 tersebut, pada baris pertemuan, pengaruh yang sesuai bersifat linear. Hal tersebut diperlihatkan oleh nilai signifikansi hasil perhitungan $p$ sebesar 0,00001 lebih kecil dari signifikansi $\alpha=0,05$ untuk linear. Dengan 
demikian, dapat dikatakan bahwa peningkatan jumlah pertemuan pada penerapan model-AfL pada pembelajaran matematika akan meningkatkan kemampuan siswa dalam matematika.

Tabel 7. Rangkuman hasil Perhitungan Tests Of Within-Subjects Contrast pada Analisis Repeated Measures

\begin{tabular}{|c|c|c|c|c|c|c|}
\hline Source & Pertemuan & $\begin{array}{l}\text { Type III Sum } \\
\text { of Squares }\end{array}$ & df & Mean Square & $\mathrm{F}$ & Sig. \\
\hline \multirow[t]{4}{*}{ Pertemuan } & Linear & 469.010 & $\overline{1}$ & 469.010 & 138.258 & .000 \\
\hline & Quadratic & 7.066 & 1 & 7.066 & 5.464 & .021 \\
\hline & Cubic & 1.740 & 1 & 1.740 & 2.055 & .154 \\
\hline & Order 4 & .262 & 1 & .262 & .300 & .585 \\
\hline \multirow[t]{4}{*}{ Pertemuan * Kelas } & Linear & 44.822 & 3 & 14.941 & 4.404 & .005 \\
\hline & Quadratic & 23.536 & 3 & 7.845 & 6.066 & .001 \\
\hline & Cubic & 5.120 & 3 & 1.707 & 2.016 & .114 \\
\hline & Order 4 & 6.783 & 3 & 2.261 & 2.582 & .056 \\
\hline \multirow[t]{4}{*}{ Error(Pertemuan) } & Linear & 498.665 & 147 & 3.392 & & \\
\hline & Quadratic & 190.118 & 147 & 1.293 & & \\
\hline & Cubic & 124.425 & 147 & .846 & & \\
\hline & Order 4 & 128.716 & 147 & .876 & & \\
\hline
\end{tabular}

a. Computed using alpha $=.05$

Langkah berikutnya, yaitu melihat pasangan pertemuan mana yang memberikan rata-rata yang berbeda. Untuk keperluan tersebut diperhatikan hasil uji post hoc (dalam hal ini menggunakan metode Bonferroni), yang rangkuman hasil perhitungannya disajikan pada Tabel 8. Tampak pada Tabel 8 tersebut, nilai signifikansi hasil perhitungan $p$ untuk semua pasangan yang diperhatikan adalah sama yaitu sebesar 0,00001. Jika nilai signifikansi hasil perhitungan tersebut dibandingkan dengan signifikansi $\alpha$ $=0,05$, maka $\alpha>p$. Dengan demikian dapat disimpulkan bahwa setiap pasang pertemuan yang diperhatikan memberikan perbedaan kemampuan siswa yang signifikan. 
Tabel 8. Rangkuman Hasil Perhitungan Uji Post Hoc pada Analisis Repeated Measures Kasus Pertemuan

\begin{tabular}{|c|c|c|c|c|}
\hline (I) Pertemuan & (J) Pertemuan & $\begin{array}{c}\text { Mean } \\
\text { Diff erence } \\
(I-J)\end{array}$ & Std. Error & Sig. $^{a}$ \\
\hline \multirow[t]{4}{*}{1} & 2 & $-.809^{*}$ & .155 & .000 \\
\hline & 3 & $-1.407^{\star}$ & .166 & .000 \\
\hline & 4 & $-1.790^{*}$ & .180 & .000 \\
\hline & 5 & $-2.302^{*}$ & .191 & .000 \\
\hline \multirow[t]{4}{*}{2} & 1 & $.809^{*}$ & .155 & .000 \\
\hline & 3 & $-.598^{\star}$ & .138 & .000 \\
\hline & 4 & $-.981^{*}$ & .142 & .000 \\
\hline & 5 & $-1.492^{*}$ & .164 & .000 \\
\hline \multirow[t]{4}{*}{3} & 1 & $1.407^{*}$ & .166 & .000 \\
\hline & 2 & $.598^{\star}$ & .138 & .000 \\
\hline & 4 & $-.383^{*}$ & .091 & .000 \\
\hline & 5 & $-.894^{\star}$ & .115 & .000 \\
\hline \multirow[t]{4}{*}{4} & 1 & $1.790^{*}$ & .180 & .000 \\
\hline & 2 & $.981^{*}$ & .142 & .000 \\
\hline & 3 & $.383^{*}$ & .091 & .000 \\
\hline & 5 & $-.512^{*}$ & .072 & .000 \\
\hline \multirow[t]{4}{*}{5} & 1 & $2.302^{*}$ & .191 & .000 \\
\hline & 2 & $1.492^{*}$ & .164 & .000 \\
\hline & 3 & $.894^{\star}$ & .115 & .000 \\
\hline & 4 & $.512^{*}$ & .072 & .000 \\
\hline
\end{tabular}

Setelah melihat perbedaan kemampuan siswa untuk setiap pertemuan, langkah berikutnya adalah melihat apakah perbedaan kelas memberikan perbedaan kemampuan siswa dalam matematika. Untuk mengetahui hal tersebut, perhatikan Tabel 9. Informasi yang disajikan dalam Tabel 9, nilai signifikansi hasil perhitungan $p$ untuk pasangan kelas VII-5 dan VII-A sebesar 0,021 serta pasangan kelas VII-5 dan VII-B sebesar 0,005. Jika nilai signifikansi hasil perhitungan tersebut disbanding-kan dengan signifikansi $\alpha=0,05$, maka $\alpha>p$. Dengan demikian dapat disimpulkan bahwa dua pasangan kelas tersebut memiliki perbedaan kemampuan matematika. Empat pasangan lainnya tidak memiliki perbedaan atau memiliki kemampuan matematika yang sama. 
Tabel 9. Rangkuman Hasil Perhitungan Uji Post Hoc pada Analisis Repeated Measures Kasus Kelas

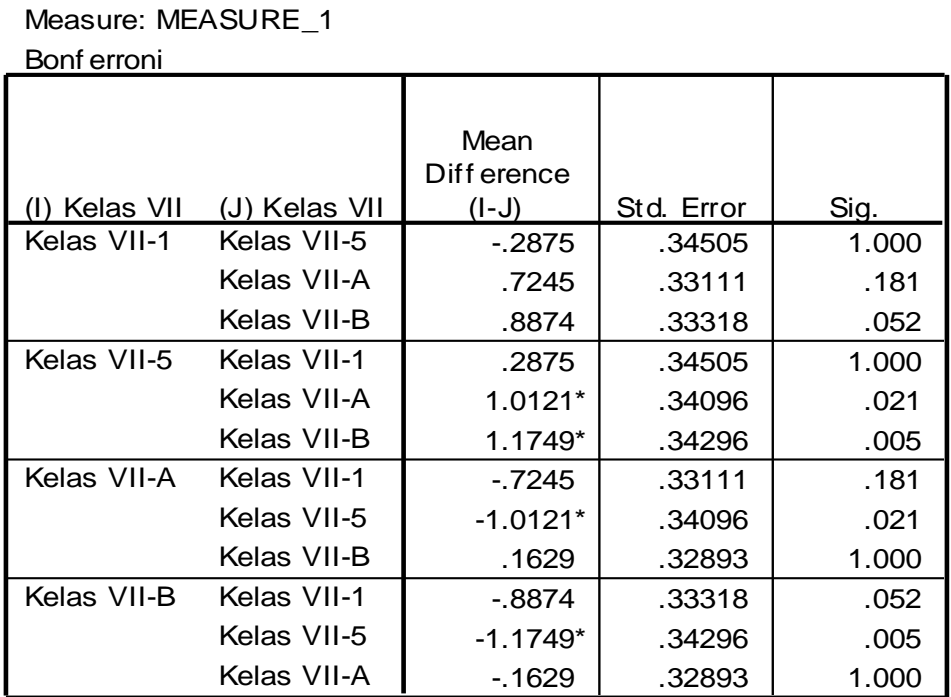

Based on observ ed means.

*. The mean difference is significant at the .05 level.

Berdasarkan hasil analisis repeated measures tersebut di atas, dapat diketahui bahwa penerapan model-AfL pada pembelajaran matematika memberikan pengaruh yang signifikan terhadap peningkatan kemampuan matematika siswa. Peningkatan kemampuan siswa mengikuti tren linear, yaitu setiap peningkatan pertemuan (tentunya disertai dengan pemberian tugas dua tahap untuk mengukur kemampuan siswa) akan memberikan peningkatan pemahaman siswa terhadap materi matematika. Kenyataan tersebut, mengindikasikan bahwa model-AfL yang diterapkan pada pembelajaran, efektif untuk peningkatan kualitas pembelajaran matematika. Di samping memberikan pengaruh pada peningkatan kemampuan, hasil penelitian juga memberikan pengaruh pada peningkatan kesadaran, motivasi, tanggung jawab, dan perilaku siswa dalam pembelajaran. 


\section{Simpulan}

Berdasarkan hasil penelitian dan pembahasan yang telah dikemukakan dalam bab sebelumnya, maka kesimpulan yang menjadi temuan penelitian ini yaitu: (1) Model-AfL pada pembelajaran matematika di Sekolah Menengah Pertama dikembangkan dengan metode research and development. Tahapan research meliputi prasurvai, analisis masalah, analisis kurikulum, studi hasil penelitian, konsultasi pakar, penyususnan prototype model. Kemudian, tahapan pengembangan meliputi validasi pakar, uji keterbacaan, pelatihan guru, ujicoba terbatas, dan ujicoba diperluas sehingga model fit secara teortis dan empiris; (2) Informasi yang dimunculkan jika menggunakan Model-AfL dalam pembelajaran adalah informasi yang akurat dan sesuai dengan kebutuhan nyata siswa dalam hal pemahaman siswa terhadap materi pembelajaran, perilaku siswa selama pembelajaran, dan kemampuan matematika siswa; (3) Pemanfaatan informasi hasil penilaian dalam Model-AfL dilakukan melalui umpan balik dan refleksi; (4) Penerapan Model-AfL dalam pembelajaran matematika meningkatkan: pemahaman, perilaku, dan kemampuan matematika siswa; dan (5) Kemajuan belajar siswa ditampilkan melalui profil individu dan profil kelas. Kedua profil tersebut menampilkan tren perkembangan pemahaman individu (atau kelas) terhadap materi pembelajaran, perilaku siswa selama pembelajaran, dan kemampuan siswa terhadap matematika untuk setiap pertemuan.

\section{Daftar Pustaka}

Assessment Reform Group. (2002). Assessment for learning: 10 principles. Norwich: DfES Publications. Diakses tanggal 02 Pebruari 2006 dari http://www.assessment-reform-group.org.uk.

Black, P. \& Wiliam, D. (1998). Inside the black box: Raising standards through classroom assessment. Phi Delta Kappan, 80(2), 139-148. 
Jurnal Penelitian dan Evaluasi Pendidikan

CEA. (Juli 2003). Quality statement on assessment practice (secondary). Diakses tanggal 01 Pebruari 2006 dari http://www.aaia.org.uk.

Cohen, B.H. (2001). Explaining psychological statistics. (2 ${ }^{\text {nd }}$ ed.). New York: John Wiley \& Sons, Inc.

Cohen, R.J \& Swerdlik, M.E. (2005). Psychological testing and assessment: An introduction to test and measurement. ( $6^{\text {th }}$ ed.). New York: McGraw Hill

Creswell, J.W. (1994). Research design: Qualitative \& quantitative approaches. Thousand Oaks: Sage Publications.

Fair Test Examiner. (1999). The value of formative assessment. Diakses tanggal 17Juni2006 dari http://www.provost.cmich.edu/assessment/ toolkit/formativesummative.html

Field, A. (2000). Discovering statistics using SPSS for Windows: Advanced techniques for the beginner. Thousand Oaks: Sage Pubications.

Grinnell, R.M. Jr. 1988. Social work research and evaluation. ( ${ }^{\text {rd }}$ ed.). Itasca, Illinois: F.E. Peacock Publisher, Inc.

Havelock, R.G. (1976). Planning for innovation: Through dissemination and utilization of knowledge. Michigan: Institute for Social Research. The University of Michigan.

Kumaidi. (2005). Profil siswa dan kelas untuk bantuan peningkatan pembelajaran. Makalah disampaikan pada Seminar Nasional Hasil Penelitian tentang Evaluasi Hasil Belajar serta Pengelolaannya, Tanggal 14-15 Mei 2005. Yogyakarta.

Kusnanto, B.A.(01 Pebruari 2006). Tiga metode baru pembelajaran matematika. Suara Merdeka, p. 1. 
Linn, R.L. (1989). Educational measurement. (3 ${ }^{\text {rd }}$ ed.). New York: Macmillan Publishing Company.

Mansyur. (2009). Pengembangan model assessment for learning pada pembelajaran matematika di SMP. Universitas Negeri Yogyakarta: Disertasi Doktor. Tidak diterbitkan.

Miller, I. \& Miller, M. (2004). Mathematical statistics with applications. ( $7^{\text {th }}$ ed.). New York: Pearson Prentice Hall.

Nitko, A.J., \& Brookhart, S.M. (2007). Educational assessment of students. New Jersey: Pearson Merrill Prentice Hall.

Pearson Education. (2006). Literacy objective: Assessment for learning. Diakses tanggal 30 Juni 2006 dari http://www.tda.gov.uk/teachers/ hottopics/assessment.aspx.

Stevens, J. (1996). Applied multivariate statistics for the social sciences. ( $3^{\text {rd }}$ ed.). New Jersey: Lawrence Erlbaum Associates.

Zulkardi. (2002). RME: Suatu inovasi dalam pendidikan matematika di Indonesia. Diakses tanggal 10 Juni 2005 dari http:/ /www.cascadeimei.com. 